\title{
Web 2.0: A Movement within the Learning Community
}

\author{
Amira Mahmoud Ahmed Atta \\ Hail University, College of Health Informatics, Saudi Arabia \\ meroata@yahoo.com
}

\begin{abstract}
Web 2.0 technologies provide members of the learning community with new and innovative ways to create disseminate and share information both individually and collaboratively. This phenomenon has been termed e-Learning 2.0. However, e-Learning 2.0 is more than the application of these technologies in the learning community; it is a movement that is beginning to transform the nature of learning. In this paper we present and explain four Web 2.0 technologies - blogs, wikis, podcasts, and social networks - and look at how these technologies are currently being used by staff. We consider the use of Web 2.0 technologies by students to find and share information and to form support communities and then we explore a Web 2.0 pedagogical model that would connect students - tomorrow's professionals - with today's professionals in order to enhance student education through providing collaborative learning opportunities together with ready access to multiple sources of information and expertise.
\end{abstract}

Keywords: Web 1.0, Web 2.0, eLearning 2.0, Social networks, Web 2.0 pedagogical model

\section{Introduction}

What is Web 2.0: Web 1.0 - a term coined in the Web 2.0 era to differentiate the two manifestations of the Web - was the first iteration of the World Wide Web. Despite the intention to create the web as a collaborative work space (Anderson, 2007) - and to some degree Web 1.0 did connect people through email, chat rooms and discussion boards (Atkinson et al., 2007) - Web 1.0 essentially consisted of static web pages providing content for consumption by "end users" or "consumers" of information. For clinicians and health professionals this meant accessing medical information in the form of web pages, online journals and trusted databases (McLean et al., 2007). "Web 2.0" is a term that is used to denote several different concepts: Web sites based on a particular set of technologies such as AJAX; Web sites which incorporate a strong social component, involving user profiles, friend links; Web sites which encourage user-generated content in the form of text, video, and photo postings along with comments, tags, and ratings; or just Web sites that have gained popularity in recent years and are subject to fevered speculations about valuations and IPO prospects. Nevertheless, these various categories have significant intersections, and so it is meaningful to talk broadly about the class of Web 2.0 sites without excessive ambiguity about which definition is being used (from now on, we use Web2 and Web1 respectively for brevity) (Graham \& Krishnamurthy, 2008). Web 2.0 is the second-generation of web companies, the rebirth after the dot-com crash. What is, and what is not, Web 2.0 is subject to debate, but here's a quick comparison to Web 1.0, see table 1, figure 1 :

Table 1: Web 1.0 vs. Web 2.0 (Jeffrey, 2009)

\begin{tabular}{ll}
\hline Web 1.0 & Web $\mathbf{2 . 0}$ \\
\hline One-way & Two-way \\
Authoritarian & Democratic \\
Passive & Active \\
Static & Dynamic \\
Closed & Collaborative \\
\hline
\end{tabular}


Figure 1: Web 1.0 vs. Web 2.0 (Jeffrey, 2009)

\section{Web 1.0 vs. Web 2.0}

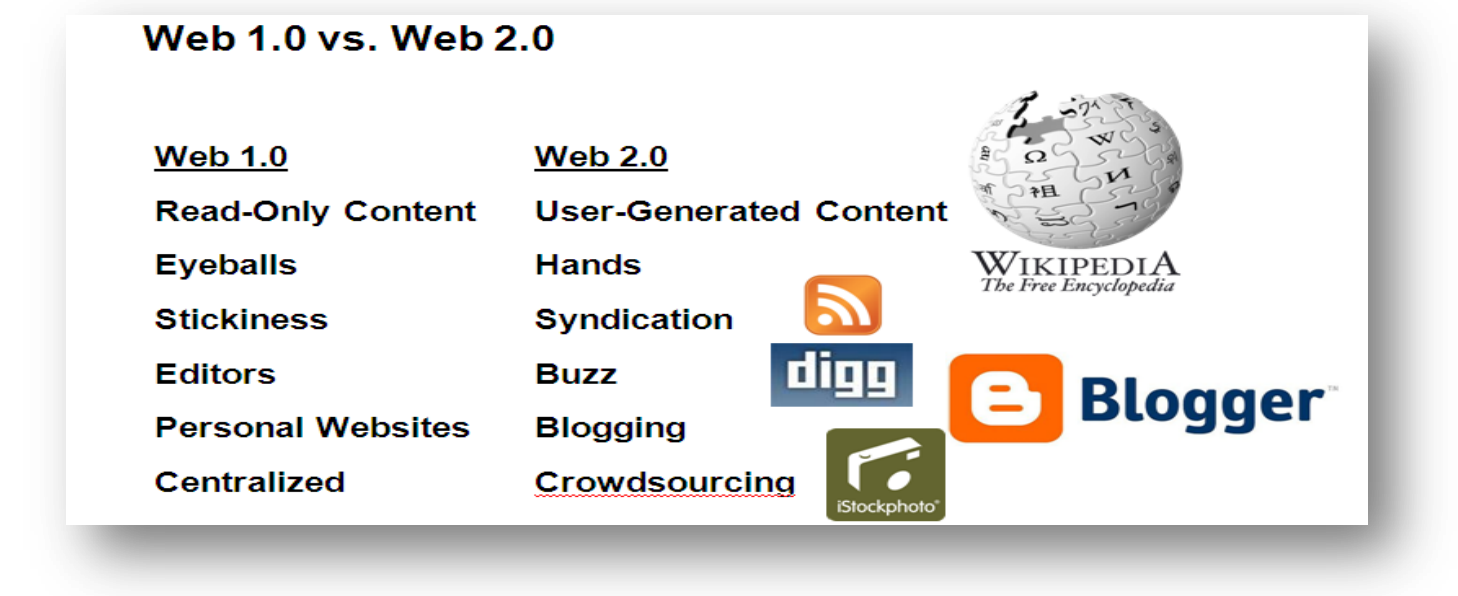

\section{From e-Learning to e-Learning 2.0}

ELearning: E-learning comprises all forms of electronically supported learning and teaching. The information and communication systems, whether networked learning or not, serve as specific media to implement the learning process (Tavangarian et al., 2004). The term will still most likely be utilized to reference out-ofclassroom and in-classroom educational experiences via technology, even as advances continue in regard to devices and curriculum. E-learning is essentially the computer and network-enabled transfer of skills and knowledge. E-learning applications and processes include Web-based learning, computer-based learning, virtual education opportunities and digital collaboration. Content is delivered via the Internet, intranet/extranet, audio or video tape, satellite TV, and CD-ROM. It can be self-paced or instructor-led and includes media in the form of text, image, animation, streaming video and audio (Wikipedia E-learning, 2012).

E-Learning 2.0: The term E-Learning 2.0 Karrer, $(2006 ; 2007)$ is a neologism for CSCL systems that came about during the emergence of Web 2.0 (Downes, 2005) From an E-Learning 2.0 perspective, conventional elearning systems were based on instructional packets, which were delivered to students using assignments. Assignments were evaluated by the teacher. In contrast, the new e-learning places increased emphasis on social learning and use of social software such as blogs, wikis, podcasts and virtual worlds such as Second Life (Redecker, 2009). This phenomenon has also been referred to as Long Tail Learning (Karrer, 2008). ELearning 2.0, by contrast to e-learning systems not based on CSCL, assumes that knowledge (as meaning and understanding) is socially constructed. Learning takes place through conversations about content and grounded interaction about problems and actions. Advocates of social learning claim that one of the best ways to learn something is to teach it to others (Seely et al., 2008). However, it should be noted that many early online courses, such as those developed by Murray Turoff and Starr Roxanne Hiltz in the 1970s and 80s at the New Jersey Institute of Technology,( Hiltz, 1990) courses at the University of Guelph in Canada,( Mason. R., 1989) the British Open University, (Mason, 1989) and the online distance courses at the University of British Columbia (where Web CT, now incorporated into Blackboard Inc. was first developed),(Bates, 2005) have always made heavy use of online discussion between students. Also, from the start, practitioners such as Harasim et al,, 1995) have put heavy emphasis on the use of learning networks for knowledge construction, long before the term e-learning, let alone e-learning 2.0, was even considered. In addition to virtual classroom environments, social networks have become an important part of E-learning 2.0 (Dunlap, 2009). Social networks have been used to foster online learning communities around subjects as diverse as test preparation and language education. Mobile Assisted Language Learning (MALL) is a term used to describe using handheld computers or cell phones to assist in language learning. Some feel, however, that schools have not caught up with the social networking trends. Few traditional educators promote social networking unless they are communicating with their own colleagues (Crane, 2009).

ELearning 2.0 - An Immediate, Important Shift: I'm a big believer in eLearning 2.0 and it's interesting to R/WW's take on eLearning 2.0. But the title - "everything you need to know" was a particularly bad choice of 
words. As you read through the post, you really don't get any sense for what eLearning 2.0 is all about. They talk about things like Nuuvo (more or less an LMS), Google Apps (online applications) as examples of eLearning 2.0 applications. Without some explanation of how they might be used in an eLearning 2.0 way this probably hurts more than helps. What might be more valuable to the readers of R/WW is to focus on the fairly fundamental shift represented by eLearning 2.0 which is very similar to the shift represented by Web 2.0. After that shift is better explained, then look at how different tools and systems might support people who are making the shift (learners) or people who are responsible for helping others make the shift (corporate training / educators). At the end of the day, eLearning 2.0 is much more than would be indicated by reading about the applications listed in this post (Karrer, 2007). But what really got to me about reading the post by R/WW was that it was easy to read it and come away with a belief that eLearning 2.0 is all about adoption of these applications. Which too many people equates to "it's about them?" And that's a problem. The most important thing to understand about eLearning 2.0 is that it is an immediately applicable and important shift in learning that applies right here and right now for most knowledge workers. Adopting a practice like blogging as a personal learning and networking tool or adopting Personal and Group Learning Using Web 2.0 Tools as a means to support collaborative work teams is something that is an immediate and important shift for knowledge workers - and that's you! The bottom line is that eLearning 2.0 is not about a bunch of applications; it's about adopting practices that leverage these applications to support work and learning in new, powerful ways (Karrer, 2007).

\section{Web 2.0 in Education}

Web 2.0 technologies provide teachers with new ways to engage students in a meaningful way. "Children raised on new media technologies are less patient with filling out worksheets and listening to lectures"(PNT Marketing Services, 2010) because students already participate on a global level. The lack of participation in a traditional classroom stems more from the fact that students receive better feedback online. Traditional classrooms have students do assignments and when they are completed, they are just that, finished. However, Web 2.0 shows students that education is a constantly evolving entity. Whether it is participating in a class discussion, or participating in a forum discussion, the technologies available to students in a Web 2.0 classroom does increase the amount they participate. Will Richardson stated in Blogs, Wikis, Podcasts and other Powerful Web tools for the Classrooms, 3rd Edition that, "The Web has the potential to radically change what we assume about teaching and learning, and it presents us with important questions to ponder: What needs to change about our curriculum when our students have the ability to reach audiences far beyond our classroom walls?" (San Francisco Chronicle, 2010) Web 2.0 tools are needed in the classroom to prepare both students and teachers for the shift in learning that Collins and Halverson describe. According to Collins and Halverson, the self-publishing aspects as well as the speed with which their work becomes available for consumption allows teachers to give students the control they need over their learning. This control is the preparation students will need to be successful as learning expands beyond the classroom" (PNT Marketing Services, 2010). Some may think that these technologies could hinder the personal interaction of students, however all of the research points to the contrary. "Social networking sites have worried many educators (and parents) because they often bring with them outcomes that are not positive: narcissism, gossip, wasted time, 'friending', hurt feelings, ruined reputations, and sometimes unsavory, even dangerous activities, [on the contrary,] social networking sites promote conversations and interaction that is encouraged by educators" (Collins, 2009). By allowing students to use the technology tools of Web 2.0, teachers are actually giving students the opportunity to learn for themselves and share that learning with their peers. One of the many implications of Web 2.0 technologies on class discussions is the idea that teachers are no longer in control of the discussions. Web 2.0 calls for major shifts in the way education is provided for students. One of the biggest shifts that Will Richardson points out in his book Blogs, Wikis, Podcasts, and Other Powerful Web Tools for Classrooms (San Francisco Chronicle,2010) is the fact that education must be not only socially but collaboratively constructed. This means that students, in a Web 2.0 classroom, are expected to collaborate with their peers. By making the shift to a Web 2.0 classroom, teachers are creating a more open atmosphere where students are expected to stay engaged and participate in the discussions and learning that is taking place around them. In fact, there are many ways for educators to use Web 2.0 technologies in their classrooms. 


\section{Web 2.0 Technologies}

In the first instance we will describe four Web 2.0 technologies - blogs, wikis, podcasts and social networks whilst providing examples of their use by eLearning professionals for information creation, information sharing, collaborative working and social networking.

Blogs: The term Blog refers to a publicly accessible web log which takes the form of a web page (Wikipedia. Blog, 2012). Blogs are used for posting information, opinions and for personal diary entries (Anderson P., 2007). Once the blog post has been published on the Web - appearing on screen usually in reverse chronological order - readers can comment on the postings and the author can respond to the comments. Blogger at (http://www.blogger.com) is a well-known blog hosting service. A blog (a portmanteau of the term web $\log$ )(Blood, 2000) is a personal journal published on the World Wide Web consisting of discrete entries ("posts") typically displayed in reverse chronological order so the most recent post appears first. Blogs are usually the work of a single individual, occasionally of a small group, and often are themed on a single subject. Blog can also be used as a verb, meaning to maintain or add content to a blog. Although not a must, most good quality blogs are interactive, allowing visitors to leave comments and even message each other via GUI widgets on the blogs and it is this interactivity that distinguishes them from other static websites (Mutum, 2010). In that sense, blogging can be seen as a form of social networking. Indeed, bloggers do not only produce content to post on their blogs but also build social relations with their readers and other bloggers (Gaudeul, 2010).

Wikis: A wiki is a website whose users can add, modify, or delete its content via a web browser using a simplified mark-up language or a rich-text editor. Wikis are powered by wiki software. Most are created collaboratively. Wikis may serve many different purposes, such as knowledge management and note taking. Wikis can be community websites and intranets, for example. Some permit control over different functions (levels of access). For example, editing rights may permit changing, adding or removing material. Others may permit access without enforcing access control. Other rules may also be imposed for organizing content (Wikipedia. Wiki, 2012).

\section{Some of the challenges in using wikis are (Eugene \& Dean, 2007):}

\section{- Lack of authority and editorial controls.}

- Wikispam: wikis are vulnerable to link spam. Spam bots dump unwanted data into wikis and are a growing threat to wiki projects. Cleaning up wikis can be time consuming and can take away from building your wiki content.

- Content: controversial topics can result in disagreements. If content is not well documented, users may debate, add, or correct information as needed. Some wikis require registration, and many private wikis require authentication every time an edit or change is made.

- Minimal use: implementing a wiki is a challenge when it is not well used. Training may be required to teach users how to learn the basics of wiki navigation and editing. Some wikis have found that they need to offer incentives for users to contribute content.

- Web 2.0 resistance: the notion of collaboration and group authoring may be at odds with an organization's work culture. Some administrators see wikis as untenable or even disruptive.

- Vandalism: the openness of most wikis means that vandalism can result. Undoing damage is annoying and time consuming.

Podcasts: A podcast is a type of digital media consisting of an episodic series of files (either audio or video) subscribed to and downloaded through web syndication. The word is a neologism derived from "broadcast" and "pod" from the success of the iPod, as podcasts are often listened to on portable media players. A list of all the audio or video files currently associated with a given series is maintained centrally on the distributor's server as a web feed, and the listener or viewer employs special client application software known as a pod catcher that can access this web feed, check it for updates, and download any new files in the series. This process can be automated so that new files are downloaded automatically. Files are stored locally on the user's computer or other device ready for offline use, giving simple and convenient access to episodic 
content.( Podcast Production,2009)( Oxford University Press | Podcast, 2011) In this way it is contrasted to webcasting (Internet streaming).

Social Networks: A social network is a social structure made up of a set of actors (such as individuals or organizations) and the dyadic ties between these actors (such as relationships, connections, or interactions). A social network perspective is employed to model the structure of a social group, how this structure influences other variables, or how structures change over time (Wasserman, 1994). The study of these structures uses methods in social network analysis to identify influential nodes, local and global structures, and network dynamics. Social networks are distinct from information, biological, or electrical networks, but theories and methods generalizing to all of these complex networks are studied in the field of network science( Scott,2003; Freeman,2004). Social networks and the analysis of them is an inherently interdisciplinary academic field which emerged from social psychology, sociology, statistics, and graph theory. Jacob Moreno is credited with developing the first sociograms in the 1930s to study interpersonal relationships as structures in which people were points and the relationships between them were drawn as connecting lines. These approaches were mathematically formalized in the 1950s and theories and methods of social networks became pervasive in the social and behavioral sciences by the 1980s (Wasserman, 1994, Borgatti, 2009). We define social network sites as web-based services that allow individuals to (1) construct a public or semi-public profile within a bounded system, (2) articulate a list of other users with whom they share a connection, and (3) view and traverse their list of connections and those made by others within the system. The nature and nomenclature of these connections may vary from site to site.

ELearning 2.0 and student empowerment: Student empowerment is a concept deeply embedded in social constructivism, both its discourse and theory. Constructivism is premised on the idea that knowledge is not a fixed object which can be transmitted from person to person, for example teacher to student, but is individually constructed through cognitive processes which involve students in the assimilation of new ideas with prior knowledge and experience (Piaget, 2000). Learning is therefore a complex and sometimes unconscious process requiring the learner to acquire, discard, modify, or reconstruct knowledge based on its application to task. The implication for the present study is that for a learning environment to be empowering, it must endeavour to support a high degree of individual variation in the way knowledge is sourced, categorised, presented and communicated so that learners have the opportunity to develop their own understandings and attributions of meaning. A second premise of social constructivism concerns the important role of social discourse in the learning process. According to this view, truths emerge when personal, possibly incomplete understandings are interrogated, questioned, justified and defended, such that learning is a product of social interaction between student and teacher and between peers (Vygotsky, 1992). Teaching is instrumental both in challenging and guiding learners towards new understandings with timely intervention and relevant feedback (Shuell, 1992). Effective learning environments must address the social aspects of learning by encouraging learners to discover and share their understandings, and debate concepts within peer networks, ultimately with a view towards transforming the classroom into a community of inquiry which extends into the wider community. To summarize this position, learning is both personal and social. It is personal to the extent that individual students must construct their own understandings. These understandings are subsequently regulated and tested through social interaction. Previously held understandings may later be disproved and thus require "reconstruction" as the student makes progress in their learning towards "better" understandings. Empowerment is part of this dialectic. The empowered student must have the "power to" explore, refine and integrate their knowledge, but also to share this "power with" other members of a community of inquiry (Duhon-Haynes, 1996; Page \& Czuba, 1999). Individual agency can be regulated through peer interaction, scaffolding, and modelling to facilitate knowledge acquisition and cognitive growth in students. In this way, the learner increasingly acquires the skills necessary to become an autonomous life-long learner. Let us turn to the relationship between empowerment and the learning environments afforded by eLearning 2.0 technologies. In so doing, we will attempt to answer the question: To what extent do eLearning 2.0 environments support social constructivism and empower student learning? Several characteristics of social constructivist learning environments have been previously identified by (Jonassen, 1994). 


\section{Conclusion}

Web 2.0 technologies give rise to new social environments which promise new possibilities for social constructivist pedagogies in blended, distance and open learning. The e-learning 2.0 movement is concerned with harnessing these tools to create learner-empowered environments which engage students in collaborative and meaning-making activities through the utility of these powerful tools (Downes, 2005). Evidence suggests that undergraduate students are rapidly adopting these tools in their private lives, to connect with friends, to build social networks and contribute to wider internet communities (Gloor, 2006; Madden, 2006). Rapid growth of these social networks is empowering a new generation of media-makers who use online tools to filter and manage content, publish photos, videos and written compositions, and rapidly communicate this information with their peers. Educators will undoubtedly continue to experiment and build new learning environments for their students. To be successful however, in a social constructivist sense, students must be invested with a degree of environmental control to accommodate their individual learning preferences. Technical and social innovation must therefore be accompanied by significant change in teaching practice. In particular, responsibility for learning and the learning environment needs to share by teacher and students. E-learning 2.0 and the ever expanding array of Web 2.0 tools offer exciting new possibilities for teachers and students to collaboratively build these social constructivist learning environments. In so doing, we empower students to realize their potential within vibrant online communities which, not coincidentally, also constitute the learning culture of our digital world.

\section{References}

Anderson, P. (2007). What is Web 2.0? Ideas, technologies and implications for education: Joint Information Systems Committee, 1-64.

Atkinson, R. J., McBeath, C., Soong, S. K. A. \& Cheers, C. (2007). Social Software and Participatory Learning: Pedagogical Choices with Technology Affordances in the Web. 24th Annual Conference of the Australasian Society for Computers in Learning in Tertiary Education, ICT: Providing Choices for Learners and Learning; 2007; Centre for Educational Development, Nanyang Technological University, Singapore. ASCILITE.

Banks use Web 2.0 to increase customer retention. (2010). PNT Marketing Services.

Bates, A. (2005). Technology, e-Learning and Distance Education London: Routledge

Borgatti, S. P., Mehra, A., Brass, D. J. \& Labianca, G. (2009). Network Analysis in the Social Sciences. Science, 323(5916), 892-895.

Blood, R. (2000). Weblogs: A History and Perspective.

Crane, B. E. (2009). Using Web 2.0 Tools in the k-12 Classroom Neal-Shuman Publishers Inc., 2009, 3

Collins, A. (2009). Rethinking Education in the Age of Technology. New York, NY: Teachers College Press, 176. ISBN 978-0-8077-5002-5.

Downes, S. (2005) E-learning 2.0, eLearn Magazine, 10/17/05. Available online at: http://www.elearnmag.org/subpage.cfm?section=articles\&article=29-1.

Downes, S. (2005). E-Learning 2.0. Downes.ca. Available online at: http://www.downes.ca/post/31741

Dunlap, J. C. \& Lowenthal, P. R. (2009). Horton hears a tweet. EDUCAUSE Quarterly, 32(4). Available online at: http://www.educause.edu/EDUCAUSE+Quarterly/EDUCAUSEQuarterlyMagazineVolum/HortonHear saTweet/192955

Duhon-Haynes, G. (1996). Student Empowerment: Definition, Implications, and Strategies for Implementation, Paper presented at the Third World Symposium (Grambling, Louisiana, March 12).

Eugene, B. \& Dean, G. (2007). Introducing web 2.0: wikis for health librarians JCHLA/JABSC, 28.

Freeman, L. (2004). The Development of Social Network Analysis: A Study in the Sociology of Science. Empirical Press. ISBN 1-59457-714-5.

Gaudeul, A. \& Peroni, C. (2010). Reciprocal attention and norm of reciprocity in blogging networks. Economics Bulletin, 30(3), 2230-2248

Gloor, P. (2006). Innovation through collaboration, Elearning! Spring, 17-21

Graham, C. \& Krishnamurthy, B. (2008). Key differences between web 1.0 and web 2.0. First Monday, 13(6 2).

Harasim, L., Hiltz, S., Teles, L. \& Turoff, M. (1995). Learning Networks: A Field Guide to Teaching and Learning Online Cambridge, MA: MIT Press. 
Hiltz, S. (1990). Evaluating the Virtual Classroom', in Harasim, L. (ed.) Online Education: Perspectives on a New Environment New York: Praeger, 133-169.

Jonassen, D. (1994). Thinking Technology: Towards a Constructivist Design Model, Educational Technology, and (April, 1994), 34-37.

Jeffrey, H. (2009). Web 1.0 vs. Web 2.0. Posted on Fri, Jan 23, 2009. Available online at: http://blog.vovici.com/blog/bid/18085/Web-1-0-vs-Web-2-0

Karrer, T. (2007). Karrer's eLearning Blog. ELearning 2.0 - An Immediate, Important Shift. Sunday, June 24, 2007. Available online at: http://elearningtech.blogspot.com/2007/06/elearning-20-immediateimportant-shift.html

Karrer, T. (2006). What is eLearning 2.0? Elearningtech.blogspot.com. Available online at: http://elearningtech.blogspot.com/2006/02/what-is-elearning-20.html

Karrer, T. (2007). Understanding eLearning 2.0. Learning circuit

Karrer, T. (2008). Corporate Long Tail Learning and Attention Crisis. Elearningtech.blogspot.com. Available online at:http://elearningtech.blogspot.com/2008/02/corporate-learning-long-tail-and.html

Mason, R. \& Kaye, A. (1989). Mind weave: Communication, Computers and Distance Education Oxford, UK: Pergamon Press

Madden, M. \& Fox, S. (2006). Riding the Waves of _Web 2.0': More than a buzzword, but still not easily defined, PEW INTERNET, October 5.

McLean, R., Richards, B. H. \& Wardman, J. I. (2007). The effect of Web 2.0 on the future of medical practice and education: Darwikinian evolution or folksonomic revolution? The Medical Journal of Australia, 187(3), 174-177.

Mutum, D. \& Wang, Q. (2010). Consumer Generated Advertising in Blogs. In Neal M. Burns, Terry Daugherty, Matthew S. Eastin. Handbook of Research on Digital Media and Advertising: User Generated Content Consumption. 1. IGI Global. 248-261.

Oxford University Press | Podcast. (2011). Oup.com. Retrieved 2011-10-24.

Page, N. \& Czuba, C. (1999) Empowerment: What Is It? Journal of Extension, 37 (5). Available online at: http://www.joe.org/joe/1999october/comm1.html

Piaget, J. (2000). Commentary on Vygotsky. New Ideas in Psychology, 18, 241-59.

Podcast Production. (2009). President and Fellows of Harvard College. Retrieved 2009-08-21.

Redecker, C. (2009). Review of Learning 2.0 Practices: Study on the Impact of Web 2.0 Innovations on Education and Training in Europe. JRC Scientific and technical report. (EUR 23664 EN - 2009). Available online at: http://ipts.jrc.ec.europa.eu/publications/pub.cfm?id=2059

Scott, W. R. \& Davis, G. F. (2003). Networks In and Around Organizations. Organizations and Organizing. Pearson Prentice Hall. ISBN 0-13-195893-3.

Small Businesses Need Innovation. (2010). New Company May Have Their Solution. San Francisco Chronicle.

Seely, B., John, A. \& Richard, P. (2008). Minds on Fire:Open Education, the Long Tail, and Learning 2.0". Educause review (January/February 2008): 16-32. Available online at: http://net.educause.edu/ir/library/pdf/ERM0811.pdf

Shuell, T. (1992). Designing instructional computing systems for meaningful learning, in Jones, M. \&Winne, P. (Eds). Adaptive Learning Environments, Springer Verlag, New York.

Tavangarian, D., Leypold, M., Nölting, K. \& Röser, M. (2004). Is e-learning the Solution for Individual Learning? Journal of e-learning, 2(4).

Vygotsky, L. (1992). Educational Psychology. Originally published 1926. Translated by Robert Silverman. St. Lucie Press, Florida.

Wasserman, S. \& Faust, K. (1994). Social Network Analysis in the Social and Behavioral Sciences. Social Network Analysis: Methods and Applications. Cambridge University Press, 1-27. ISBN [[Special: BookSources/978521382694|978521382694]].

Wikipedia. E-learning. Last view 1 June 2012. Available online at: http://en.wikipedia.org/wiki/E-learning Wikipedia. (2012). Blog. Last view 1 June 2012. Available online at: http://en.wikipedia.org/wiki/Blog Wikipedia. (2012). Wiki Last view 1 June 2012. Available online at: http://en.wikipedia.org/wiki/Wiki 